\title{
Principal Management in Improving the Education Quality: A Case of SMA Inshafuddin, Banda Aceh
}

\author{
Raudhatul Juniati, Yusrizal, Niswanto \\ Graduate School of Education Administration, Universitas Syiah Kuala, Indonesia. \\ *Corresponding email: rjanakbaik@gmail.com
}

Received: 09 October 2021

Accepted: 20 November 2021

Published: 16 December 2021

\begin{abstract}
This research aims to examine and analyze the program, the principal in improving the education quality at Inshafuddin Senior High School of Banda Aceh. This research uses the descriptive analysis method with qualitative method. The technique of data collection used are observation, interview, and documentation. The subject of this research are principal, teachers, and supervisors. The result of the research shows that: (1) The preparation of theof the principal's program includes: a long-term annual program of eight years, a medium-term four-year period and a short-term once a year. (2) The implementation of the principal's program is carried out by division of tasks, conducting training and attending MGMP, condukting laboratoryn and library monitoring and axamination at the and of each school year and providing guidance for teavchers who are less participating. (3) Evaluation of the program is carred out by the committe team namely the school principal, representatives, senior teachers and supervisors using the intrument and the results of the evaluation aredocumented. (4) The obstacles include: the efficiency of the discipline and the effeciency of the interest in reading students in accalerating.
\end{abstract}

Keywords: principal management, education quality, senior high school.

Abstrak: Penelitian ini bertujuan untuk mengkaji dan menganalisis program kepala sekolah dalam meningkatkan mutu pendidikan di SMA Inshafuddin Banda Aceh. Penelitian ini menggunakan metode deskriptif analisis dengan metode kualitatif. Teknik pengumpulan data yang digunakan adalah observasi, wawancara, dan dokumentasi. Subjek penelitian ini adalah kepala sekolah, guru, dan supervisor. Hasil penelitian menunjukkan bahwa: (1) Penyusunan program kepala sekolah meliputi: program tahunan jangka panjang delapan tahun, jangka menengah empat tahun dan jangka pendek setahun sekali. (2) Pelaksanaan program kepala sekolah dilakukan dengan pembagian tugas, mengadakan pelatihan dan mengikuti MGMP, melakukan pemantauan dan pemeriksaan laboratorium dan perpustakaan pada setiap tahun pelajaran dan setiap tahun ajaran serta memberikan pembinaan bagi guru yang kurang berpartisipasi. (3) Evaluasi program dilakukan oleh tim panitia yaitu kepala sekolah, perwakilan, guru senior dan pengawas dengan menggunakan instrumen dan hasil evaluasi didokumentasikan. (4) Kendala tersebut antara lain: efisiensi kedisiplinan dan efisiensi minat baca siswa dalam akselerasi.

Kata kunci: menejemen kepala sekolah, kualitas pendidikan, sekolah menengah atas.

\section{To cite this article:}

Juniati, R., Yusrizal, \& Niswanto. (2021). Principal Management in Improving the Education Quality at Inshafuddin Senior High School of Banda Aceh. Jurnal Pendidikan Progresif, 11(3), 632-639. doi: 10.23960/jpp.v11.i3.202114. 


\section{INTRODUCTION}

Education in a country is very important to ensure the survival of the country and nation. Education as an effort to direct the development of students in accordance with the norms and values that develop and are accepted by society. Education is a vehicle for improving and developing the quality of human resources. According to Law no. 20 of 2003 concerning the national education system, education is a conscious and planned effort to create a learning atmosphere and learning process so that students actively develop their potential to have religious spiritual strength, self-control, personality, noble moral intelligence, and skills needed by themselves, society, nation and state. Creating qualified schools is not a very easy thing. Quality is a continuous development of a stable system where the need for efforts to improve the quality of education by looking at the output of qualified graduates and not only limited to graduating. Quality is an overall description and characteristic of goods or services that show their ability to satisfy expected or implied needs.

Efforts to improve quality involve all school personnel who in the process demand a shared commitment to the quality of education in schools, growing commitment among school personnel through the role of the principal as an education leader. At least, there are five service characteristics must be realized by the principal so that customers are satisfied, namely service as promised (relialibility), able to guarantee the quality of learning (assurance), a conducive (tangible) school climate, giving attention full of students (emphaty), and responsive to the needs of students (responsiveness). The principal has a very influential role in coordinating the mobilization and harmonization of all available educational resources in the school (Zuilkowski, Piper, Ong'ele, \& Kiminza, 2018; Griffith et.al., 2017; Meyers \& Hambrick, 2017).
The principal has a very influential role in coordinating the mobilization and harmonization of all available educational resources in the school. School principals are highly demanded by school management capabilities, namely management of strategies to improve the quality of education and management of school-based quality improvement. However, the reality that is happening now in the context of education is still weak, so the quality aspect is neglected because it is one of the factors of the management of a principal's leadership. The lack of opportunity for principals in coaching and supervising teachers and other staff will be a problem and obstacle in achieving the school's vision and mission, so that it will have a negative effect on the quality of the school. So the researchers are interested in conducting research at Inshafuddin High School regarding the management of principals in improving the quality of education.

\section{THEORETICAL FRAMEWORK}

\section{Educational Management Concepts}

Management is a process or framework that involves the guidance or direction of a group of people towards organizational goals or tangible goals (Ololube, 2017). The word "management" comes from the Latin word from the word "manus" which means hand and "agere" which means to do. These words are combined into the verb 'management' which means to handle. Managere is translated into English in the form of verbs to manage, with noun management, and managers for people who carry out management activities. Finally, management is translated into Indonesian. Management is the science and art of organizing, controlling, communicating and utilizing all available resources in the organization by utilizing management functions (Planing, Organizing, Actuating, Controling) so that the organization can achieve its objectives effectivly 
and efficienly. The better the education of a nation, the better the quality of the nation. actually education describes the activities of a group of people such as teachers and other education personnel carrying out education for young people in collaboration with interested people.

Good education management is understood as science, art, profession, process and or activities so far it has become an important part of the process of organizing education. Education management can be understood as an activity that guiding the resources of an educational organization through a process of planning, organizing, directing, mobilizing, communicating, controlling, evaluating and budgeting directed to achieve the stated educational goals. Integration of educational organization resources takes place in a comprehensive system, structure, method, strategy and policy. So, the above opinion can be concluded that the management of education as action and various steps in supporting quality education that is influenced by all educational devices.

\section{Management of Education Quality Improvement}

The quality of education as one of the pillars of human resource development is very important meaning for national development. Therefore, efforts to improve the quality of education are strategic points in efforts to create quality education (Kairys, 2018; Anderson, Ellwood, \& Coleman, 2017; Dandan, \& Marques, 2017). Quality is a measure of the good or bad of an object, the level or degree of form, intelligence, intelligence, skills and so on. Quality of education is two terms derived from quality and education, meaning that it refers to the quality of products produced by educational institutions or schools, which can be identified from the number of students who have achievements, both academic achievement and others, as well as graduates relevant to the objectives (Serdyukov, 2017; Wong, \& Daud, 2017).

Quality is something that satisfies and exceeds the desires and needs of a person or group of people. Good quality has always been everyone's dream, especially in the field of education. The quality of education is the quality of graduates and services that satisfy parties related to education. Quality of graduates relating to graduates with good grades (cognitive, affective and psychomotor) is accepted to continue to a higher level of quality and have a good personality. While the quality of services related to activities to serve the needs of students, teachers and employees and the community appropriately and precisely so that all are satisfied with the services provided by the school.

Improving the quality of education it is necessary to make changes, namely: 1) Schoolbased Quality Management in which schools are given the authority to plan their own overall quality improvement efforts; 2) Education based on community participation (community based education) where positive interactions occur between schools and the community, schools as community learning centers; and 3) Using a learning paradigm that will make students or learners become empowered human beings (Mohammed, 2016).

Management of improving the quality of education is a method of improving quality that relies on the institution itself, applying a collection of techniques, basing on the availability of quantitative and qualitative data and empowering all components of educational institutions to continuously increase capacity and the ability of the organization to meet the needs of students and society (Bush, Bell, \& Middlewood, 2019; Chan, 2018; Baharudin, 2017; Cajiao, \& Burke, 2016). So it can be concluded that the quality of education needs good management from all aspects, especially from head management, teacher management, learning curriculum 
management, infrastructure and school financialmanagement (Jamli, 2019; Bairaðauskienë, 2017; Böhlmark, Grönqvist, \& Vlachos, 2016).

\section{School Principal Management in Education Management}

In the perspective of National education policy, Minister of National Education Regulation No. 13 of 2007, there are seven main roles of the principal, namely, as educators, managers, administrators, providers, leaders, creators of work climate and entrepreneurship.

\section{The principal as an educator}

Principals who show high commitment and focus on curriculum development and teaching and learning activities in their schools, of course, always try to facilitate and encourage teachers to continuously improve their competence, so that teaching and learning activities can run effectively and efficiently.

\section{The principal as a manager}

In this case, the principal should be able to facilitate and provide extensive opportunities for all teahers to be able to carry out professional development activities through various education and training activities, both carried out in schools such as the School Level Teachers Working Group (MGMP), professional discussion and so on or through education and training activities outside of school such as opportunities to continue education or participating in various activities organized by other parties.

\section{The principal as an administrator}

Particularly with regard to financial management, to achieve increased teacher competence is inseparable from the cost factor. How much schools can allocate a budget, the increasing in competence will certainly affect the level of teacher competency. Therefore the school principal can always allocate an adequate budget for efforts to improve teacher competency.

\section{The principal as a provider}

To find out to what extent the teacher is able to carry out learning, the principal needs to carry out supervision activities periodically which can be done through classroom visits to observe the learning process directly, especially in the selection and use of appropriate teaching methods, learning media used and student order in learning process.

\section{The principal as a leader}

Principal's leadership can foster creativity while at the same time can encourage teacher competency improvement. In leadership theory, we know at least two leadership styles, namely task-oriented leadership and human-oriented leadership. In order to improve teacher competency, a school principal can apply both leadership styles appropriately and flexibly, adapted to the existing conditions and needs. Leadership of a school principal is closely related to personality, and the principal's personality as a leader will be reflected in his qualities of being authoritative, honest, trustworthy, responsible, communicative, and courageous in taking risks and decisions, soulful, emotionally stable and exemplary.

The principal as the creator of the working atmosphere

A conducive work culture and climate will enable each teacher to be more motivated to show superior performance, accompanied by efforts to show their competence.

The principal as an entrepreneur

In applying the principles of entrepreneurship linked to increasing teacher 
competence, the head of the school can always create renewal, comparative advantage, and utilize resources and challenges as opportunities. The school principal with a strong entrepreneurial attitude will dare to make innovative changes in the institution he leads, including changes in matters relating to the learning process of students and the competence of their teachers.

From the seven roles of school principals in managing education, we can conclude that school principals are very influential in forming quality schools, because the role of the school as a great guide for their subordinates if the principal is successful in carrying out his duties and responsibilities as a leader, then the vision and mission of the school will be achieved. Several things that determine the realization of a quality educational process include: a) the effectiveness of the principal's leadership style; b) active participation and sense of responsibility of teachers and staff; c) continuity of effective teaching and learning processes; d) relevant curriculum; e) have a directed vision and mission; f) a conducive school climate, and g) intrinsic involvement of parents and the community (Adams, Olsen, \& Ware, 2017; Kempa, Ulorlo, \& Wenno, 2017; Yieng, \& Daud, 2017).

The ten keys to the success of a school principal are the leadership of the principal in relation to the various tasks and functions that he must carry out in creating an effective, productive, independent, and accountable school. So to achieve this, there are ten keys that will help the success of the principal in his leadership. The ten keys to success are as follows: a) full vision; b) responsibility; c) example; d) empower staff; e) listen to other people; f) providing excellent service; g) develop people; $\mathrm{h}$ ) empower schools; i) focus on students; j) management that empowers practice. So it can be concluded that, the principal's management in the management of education, the principal must be good at theorizing and practicing good ideas in concrete actions so that the educational goals are realized in accordance with the vision and mission of the school that has been set at the school.

\section{- METHODS \\ Qualitative descriptive method was used} in this study. Qualitative research is research that emphasizes quality or the most important thing about the nature of an item. The most important thing about an item or service in the form of an efen /phenomenon/social phenomenon is the meaning behind the even which can be used as a valuable lesson for the development of a theoretical concept.

The collection of principal's management information data is collected through observasion, interviews, results of photographs, documentation analysis. the researcher analyzes the data by enriching the information, looking for relationship, analysis, comparing finding pattems on the basis of the original data (not tranformed in the form numbers). this research was conducted at Inshafuddin Senior High School Of Banda Aceh. The subjects of this study are principal, teachers, and supervisor

\section{RESULTS AND DISCUSSION}

The Principal Program at Inshafuddin High School is compiled together, namely the RKTS (School Annual Work Plan) program, which is a long-term annual program, which once every eight years includes: the field of development and public relations, the medium term, which is once every four years, including: curriculum, students, equipment, and infrastructure equipment. And the short-term annual program includes: teacher teaching and training programs. The teaching program consists of: teacher needs, division of teaching tasks, procurement of textbooks, learning tools and teaching aids, procurement of 
laboratories, assessment of learning outcomes, curricular activities. Whereas the teacher training program consists of: MGMP training, IT (Information Technology) training and Ereport card training. The principal made an education implementation program based on improving the quality of Inshafuddin's High School. The quality improvement program is documented in the long-term, medium-term and short-term annual programs to be used as reference material in program implementation. Planning is an ideal that is realized through a decision to formulate what will be carried out in the future so that it helps the organization in achieving its goals.

Implementation of the headmaster's program at Inshafuddin High School the headmaster first forms an executive committee team and assigns tasks to professional and responsible personnel and the headmaster determines the schedule of implementation activities before the headmaster gives directions before the program is implemented. If the principal is unable to attend, the assignment is given to the representative so that the program is carried out. The implementation of the program that has been made must be consistent without distortion, while paying attention to the effectiveness and efficiency factors". For the implementation of an effective teaching and learning process, the principal must create a work team consisting of teachers in a professional and proportional manner.

The evaluation of the headmaster's program at Banda Aceh's Inshafuddin High School was carried out by a team committee formed by the headmaster which included the principal, the deputy headmaster of the senior teacher and supervisor. And before that the committee had prepared the instrument so that the evaluation was directed. After the evaluation results are obtained where there are deficiencies then the implementation team created a new program in the form of an annual program to be implemented in the following year. Evaluation is a systematic process of collecting and analyzing data for decision making. While program evaluation is a process of collecting and analyzing data so that it becomes a broad and comprehensive activity that is used to make important decisions related to the program or project being assessed.

The obstacles include: Limited time for school principals, limited infrastructure, some teachers lack discipline and students' interest in reading students is still low. the principal's job was: The principal is responsible and accountable. The principal acts and is responsible for all actions carried out by subordinates. Compliance is done by subordinates. The deeds done by teachers, students and staff and parents of students cannot be separated from the responsibility of the principal. With limited time and resources, the principal must be able to face various problems. With all the limitations, a school principal must be able to arrange assignments appropriately and can prioritize if there is a conflict between the interests of the interests of subordinates with the interests of the school.

The principal must think analytically and conceptually. The principal must be able to solve the problem through an analysis, then solve the problem with a flexible solution. The principal is a mediator or mediator. In the school environment as an organization there consists of people who have different backgrounds that can cause conflict, therefore the principal must be an intermediary in the conflict. The principal is a politician. The principal must be able to build cooperation through a persuasion and agreement approach.

The principal is a diplomat. In various kinds of meetings the principal is the official 
representative of the school he leads. The principal makes difficult decisions. There is no single organization that can run smoothly without problems. Likewise, schools as an organization are not free from problems and difficulties.

\section{- CONCLUSIONS}

Based on the results of the study the authors concluded that the principal's management in improving the quality of education in SMA Inshafuddin was: The Inshafuddin Banda Aceh High School Principal Program includes: The preparation of theof the principal's program includes: a long-term annual program of eight years, a medium-term four-year period and a short-term once a year.

Implementation of the program carried out by the principal by creating an implementation team to carry out their duties and responsibilities. And the principal does not forget the task as a leader who provides a good example in carrying out the task in a timely manner not to procrastinate unless absent. The principal always controls his subordinates at work.

The evaluation of the headmaster's program at Banda Aceh's Inshafuddin High School was carried out by a team committee formed by the headmaster which included the principal, the deputy headmaster of the senior teacher and supervisor. And before that the committee had prepared the instrument so that the evaluation was directed. After the evaluation results are obtained where there are deficiencies then the implementation team created a new program in the form of an annual program to be implemented in the following year. The obstacles include: Limited time for school principals, limited infrastructure, some teachers lack discipline and students' interest in reading students is still low.

\section{REFERENCES}

Adams, C. M., Olsen, J. J., \& Ware, J. K. (2017). The school principal and student learning capacity. Educational Administration Quarterly, 53(4), 556-584. Anderson, L., Ellwood, P., \& Coleman, C. (2017). The impactful academic: Relational management education as an intervention for impact. British Journal of Management, 28(1), 14-28.

Baharuddin, M. (2017). The Influence of Diploma Background Working Life And Situational Leadership Factor Of Headmaster Toward The Performance of Head of State School in Samarinda. European Journal of Research and Reflection in Educational Sciences Vol, 5(4).

Bairaðauskienë, L. (2017). Headmaster's competencies in management area: evaluating the significance level of managerial competencies in Lithuanian comprehensive schools. European Journal of Multidisciplinary Studies, 2(5), 158164.

Böhlmark, A., Grönqvist, E., \& Vlachos, J. (2016). The headmaster ritual: The importance of management for school outcomes. The Scandinavian Journal of Economics, 118(4), 912-940.

Bush, T., Bell, L., \& Middlewood, D. (Eds.). (2019). Principles of Educational Leadership \& Management. SAGE Publications Limited.

Cajiao, J., \& Burke, M. J. (2016). How instructional methods influence skill development in management education. Academy of Management Learning \& Education, 15(3), 508-524.

Chan, M. L. (2018). Management education in the People's Republic of China. In Management Issues in China: Volume 1 
(pp. 237-257). Routledge.

Dandan, M. M., \& Marques, A. P. (2017). Higher education leadership and gender gap in Jordan. Asian Development Policy Review, 5(3), 131-139.

Griffith, K. G., Jones, K., Howard, E., \& Winship, J. (2017). Rural School Administrators'perceptions Of Educators'skills Needed For Effective Inclusion Classrooms. City Meets Country: Educators Working to Solve the Challenges of Special Education, 60, 52.

Jamli, N. F. A., \& Salim, S. S. S. (2019). Development of an Instrument to Evaluate Emotional Intelligence and Leadership Style of Headmasters across Primary Schools in Malaysia. International Journal Of Academic Research In Business And Social Sciences, 9(7).

Kairys, M. R. (2018). The influence of gender on leadership in education management. International Journal of Educational Management.

Kempa, R., Ulorlo, M., \& Wenno, I. H. (2017). Effectiveness Leadership of Principal. International Journal of Evaluation and Research in Education, 6(4), 306-311.

Meyers, C. V., \& Hambrick Hitt, D. (2017). School turnaround principals: What does initial research literature suggest they are doing to be successful?. Journal of Education for Students Placed at Risk (JESPAR), 22(1), 38-56.

Mohammed, K., Alotibie, B. A., \& Abdulaziz, A. (2016). Total quality management in Saudi higher education. International Journal of Computer Applications, 135(4), 6-12.

Ololube, N. P., Agbor, C. N., \& Agabi, C. O. (2017). Effective leadership and management in universities through quality management models. In Innovation and Shifting Perspectives in Management Education (pp. 224-245). IGI Global.

Serdyukov, P. (2017). Innovation in education: what works, what doesn't, and what to do about it?. Journal of Research in Innovative Teaching \& Learning.

Wong, A. Y., \& Daud, K. (2017). Headmaster Technology Leadership in Malaysia Elementary Schools. Journal of Education and Learning, 11(2), 154-164.

Yieng, W. A., \& Daud, K. B. (2017). Technology leadership in Malaysia's high performance school. Journal of Education and e-Learning Research, 4(1), 8-14.

Zuilkowski, S. S., Piper, B., Ong'ele, S., \& Kiminza, O. (2018). Parents, quality, and school choice: why parents in Nairobi choose low-cost private schools over public schools in Kenya's free primary education era. Oxford Review of Education, 44(2), 258-274. 